\title{
REVIEWS
}

\section{Engaging Patients and Other Non-Researchers in Health Research: Defining Research Engagement}

\author{
Lori Frank, $P h D^{7}$, Sally C. Morton, $P h D^{2}$, Jeanne-Marie Guise, MD, $\mathrm{MPH}^{3}$, \\ Janet Jull, OT Reg, PhD 4 , Thomas W. Concannon, PhD ${ }^{5}$, and Peter Tugwell, MD, MsC for \\ the Multi Stakeholder Engagement (MUSE) Consortium
}

\begin{abstract}
'RAND Corporation, Washington, DC, USA; ${ }^{2}$ Department of Statistics, College of Science, Virginia Tech, Blacksburg, VA, USA; ${ }^{3}$ Departments of Obstetrics and Gynecology, Medical Informatics \& Clinical Epidemiology, Emergency Medicine, Oregon Health \& Science University School of Medicine and the OHSU-PSU School of Public Health, Portland, OR, USA; “School of Rehabilitation Therapy, Queen's University, Kingston, ON, Canada; ${ }^{5}$ The RAND Corporation, Boston, MA, USA; ${ }^{6}$ Canada Research Chair in Health Equity, University of Ottawa Centre for Global Health, Ottawa, ON, Canada.
\end{abstract}

With the increase in patient and consumer activism through the late twentieth century and into this century, patient roles in research evolved into a new model of research engagement, with patients serving as active advisors and co-leading or leading clinical research. By requiring active engagement of patients and other stakeholders, several government research funders have advanced this model, particularly in Canada, the United States (US), United Kingdom (UK), and Australia. A consortium of individuals from these countries formed a Multi-Stakeholder Engagement (MuSE) consortium to examine critical issues in engaged research, establish consensus on definitions, and provide guidance for the field, beginning with an overview of how to involve stakeholders in health research (Concannon et al. J Gen Intern Med. 2019;34(3):458-463) and continuing here with an examination of definitions of research engagement. The political and advocacy roots of engaged research are reflected in definitions. Engagement is conceptualized with reference to research project goals, from informing specific clinical decisions to informing health-system level decisions. Political and cultural differences across countries are evident. Some of these government funders focus on empirical rather than ethical rationales. In countries with centralized health technology assessment, the link between societal values and engaged research is explicit. Ethical rationales for engagement are explicit in most of the published literature on research engagement. Harmonization of definitions is recommended so that research engagement elements, methods, and outcomes and impacts can be clearly examined and understood, and so that the field of research engagement can proceed from a clear conceptual foundation. Specific recommendations for terminology definitions are provided. Placing engaged research on a continuum from specific clinical decisions to more

$\overline{\overline{\text { Prior presentations } \text { This paper has not been presented at any previous }}}$ conferences.

Electronic supplementary material The online version of this article (https://doi.org/10.1007/s11606-019-05436-2) contains supplementary material, which is available to authorized users.

Received November 27, 2018

Revised April 24, 2019

Accepted September 18, 2019

Published online November 11, 2019 global public and social justice concerns clarifies the type of engaged research, supports appropriate comparisons, and improves the rigor of engaged research methods. The results help identify knowledge gaps in this growing field.

KEY WORDS: stakeholder engagement; patient engagement; international health; patient-centered outcomes research.

J Gen Intern Med 35(1):307-14

DOI: $10.1007 / \mathrm{s} 11606-019-05436-2$

(C) Society of General Internal Medicine 2019

\section{INTRODUCTION}

The influence of healthcare consumers-mostly patients - dramatically increased in the late twentieth century. Activist consumers wielded new influence on healthcare and health policy across therapeutic areas ranging from cancer to perinatal care, AIDS, and mental health. ${ }^{1,2}$ Increased activism of citizens in politics and changing views of political power structures preceded and likely contributed to the rise of patient activism $^{3}$ and changes in the patient-clinician relationship. In the United States (US), direct-to-consumer advertising for pharmaceuticals altered the information asymmetry that had been the historical hallmark of patient-clinician interactions. ${ }^{4}$ Internet search technology increased access to health information for patients, further altering consumer access to health information. ${ }^{5}$ The changes in power relationships between patient and clinician extended to research subjects and researchers. AIDS activists and cancer advocacy organizations brought attention to clinical treatment access, leading to enhanced "citizen control" in drug regulation, connecting the consumerist movement to clinical research. ${ }^{6,7}$

Through the 1980s and 1990s, action-oriented health and policy research was increasingly organized into a coherent field. ${ }^{3,7}$ This community-based participatory research (CBPR) movement continues to this day, but in the 1990s participatory research expanded to include less directly advocacy-focused clinical research. Rather than change CBPR, this expansion resulted in a new paradigm for inclusion of patients and others affected by clinical research. The term "engaged research" is 
used here to denote this new paradigm of involving patients in research activities traditionally handled only by researchers, with patients serving as advisors to researchers, as consultants for specific aspects of research design and/or outcomes selection, and/or as co-investigators with responsibility and intellectual contribution equal to that of the trained clinical researchers.

One result of the uptake of the engaged research model has been formal attention from governmentbased research funders, with funding support for either voluntary or mandatory inclusion of patients and other end-users of research. The National Institutes of Health Research (NIHR) in the UK has advanced engaged research through formal engagement requirements in clinical research along with infrastructure to support public involvement, including for the James Lind Alliance, the NIHR-funded public priority setting organization, ${ }^{8}$ and for INVOLVE, the NIHR-supported group for advancing active public involvement in the UK National Health Service, and public health and social care research. ${ }^{8,9}$ The Canadian Institutes of Health Research (CIHR) established the Strategy for Patient Oriented Research to support engaged research among Canadian health research awardees. ${ }^{10}$ The Patient-Centered Outcomes Research Institute (PCORI) in the US requires engaged research in its funding. ${ }^{11}$ In Australia, the National Health and Medical Research Council established guidelines for consumer and community involvement in health research in 2005, with an update in 2016. ${ }^{12}$

A consortium of individuals from Canada, the US, the UK, and Australia has formed a Multi-Stakeholder Engagement (MuSE) Consortium to examine critical issues in engaged health research, establish consensus on definitions, and provide guidance for the field. MuSE research projects test specific hypotheses but the Consortium's broader scope is to study health evidence including primary qualitative and quantitative studies and syntheses of health systems evidence, health policy evidence, public health evidence, health technology assessment, health economic evidence, and knowledge translation studies including guidelines.

The MuSE Consortium has as one focus defining research involvement and all forms it can take. To guide the MuSE Consortium, we examined definitions of research engagement and research stakeholders from government-based funders in these countries and provide recommendations for harmonizing definitions.

There are three initial distinctions to be made in order to identify a useful definition of research engagement. Specifically, distinction can be made between (1) patient and clinician involvement in clinical care, (2) public involvement in setting broad research priorities at a societal level ${ }^{13,14}$ distinct from contributions to specific research projects, and (3) patient involvement in the conduct of specific research projects. The last category-patient involvement in specific research projects - is the focus here. Further distinction needs to be made between types of involvement. We exclude involvement solely as research subjects and focus instead on "research partnership" which entails patient involvement as advisors, consultants, and/or research team members, including as coinvestigators. We therefore include only those activities from the summary of stakeholder engagement plans presented by Concannon et al. ${ }^{15}$ that relate to specific project work, whether they are part of "Preparing for Research," "Conducting Research," or "Using Research." The definitions reviewed here are those relating to involvement of non-researcher patients in specific research projects.

\section{METHODS}

The PCORI Engagement in Health Research Literature Explorer (https://www.pcori.org/literature/engagement-literature; see online Appendix 1 for search terms and additional details) was the initial source for material to include in this landscape review for several reasons. It provides updated surveillance of research engagement literature from PubMed/MEDLINE and it provides a categorization of that material by topical focus. Articles meeting search criteria for inclusion in the Literature Explorer repository are reviewed and categorized by PCORI staff into four categories (not mutually exclusive): projectspecific; engagement methods; evaluation; and framework, editorial, or commentary. This last category captures articles with conceptual and definitional material relevant to the goals of this MuSE work. For this work, we selected only those articles from the Literature Explorer that were categorized as having a conceptual and definitional focus. Articles in this category were downloaded from the June 2018 repository for review and consideration for inclusion in this landscape review. Of the retrieved results, abstracts were reviewed and those articles addressing research engagement definitions were retrieved for full review. The reference sections of retrieved articles were searched to identify additional literature relevant to definitions. In addition, definitions of research engagement and stakeholders were collected from publicly available materials from the funders, specifically the funder websites and relevant materials, limited to those that included definitions of engagement for each of the four countries represented in MuSE: Canada, the US, the UK, and Australia. LF was the main reviewer, with $\mathrm{JJ}$ serving as the secondary reviewer.

\section{RESULTS}

Of the 277 articles in the category of "framework, editorial, commentary," that is, the tagged category that includes articles with conceptual and definitional material relating to research engagement, 220 were included as relevant to defining research engagement based on review of the abstracts. Of those, 25 articles contained content relevant to the definitions aim and were included in this review. The reference sections of those 25 articles were examined and six additional funder 
websites or reports were identified as relevant to the aims here and were retrieved and reviewed as well.

\section{Definitions of Engaged Research}

\section{Funding agencies}

Definitions of research involvement or engagement collected from publicly available materials of major funders of clinical research in Canada, the UK, the US, and Australia are examined below. Major research funders refer to the concept of active research involvement variously as "patient and public involvement" (NIHR), "patient-oriented research" and "patient engagement" (CIHR), "engaged research" (PCORI), ${ }^{16}$ and "consumer and public involvement". ${ }^{12}$ See Table 1 for detailed text of relevant definitions. Key features that emerge across each of these definitions, the "who, why, how, and what" are compared in Table 2. Table 3 provides definitions of stakeholders by funder, relevant for definitions. Finally, the definitions span a continuum from a focus on interactions between clinicians and patients, to practice level and health system level interactions, to a more global focus on population health, social justice, and societal equity. The continuum provides a useful way to organize and compare across funder definitions (see Fig. 1).

CIHR. See Table 1 for the CIHR guiding definition. Several aspects of this definition are of interest. First, it calls out "patients as partners" as a hallmark of patient-oriented research. Reference is made to "relevant stakeholders," suggesting that inclusion of patients is required to meet a definition of patient-oriented research but other non-patient stakeholders may also be engaged. Second, patient-oriented research addresses priorities important to patients. Third, it incorporates the goals in the definition, that of improving patient outcomes as well as applying knowledge to improve healthcare systems and practices. The CIHR definition emphasizes the public health rationale of research engagement and reflects the knowledge translation orientation of the CIHR, a link made more explicit in the definition of "patient engagement" (see Table 1). References to equity within a CIHR discussion of the goals of "patient-oriented research" suggest a link to the goals of CBPR:

Patient engagement in SPOR: An important goal of Canada's Strategy for Patient-Oriented Research (SPOR) is for patients (an overarching term inclusive of individuals with personal experience of a health issue and informal caregivers, including family and friends), researchers, health care providers and decision-makers to actively collaborate to build a sustainable, accessible and equitable health care system and bring about positive changes in the health of people living in Canada.
PCORI. The PCORI definition also references the public health rationale, but more narrowly, with focus on uptake and use of research results as the ultimate goal (see Table 1). In distinction with the CIHR definition, while partnership with patients in production of research is included, it is partnership with stakeholders generally, and not necessarily patients, that is required (see Table 2 for comparisons). The rationale and goals for research engagement include addressing patient priorities, and like the CIHR definition, the downstream goals include improving uptake of research. PCORI emphasizes the more specific and less global goal of improving decision making in clinical encounters, however. The strategic plan and the definition of engagement maintain the focus on improving decision making "locally" within the patient/clinician encounter and within specific health systems, rather than globally:

We seek to fund useful research likely to change practice and improve patient outcomes... we work to influence research funded by others to become more useful to patients and other healthcare decision makers. (https://www.pcori.org/about-us)

The PCORI mission addresses the global goal of improving healthcare generally, while stressing the specific healthcare decision focus:

PCORI helps people make informed healthcare decisions, and improves healthcare delivery and outcomes, by producing and promoting high-integrity, evidence-based information that comes from research guided by patients, caregivers, and the broader healthcare community. (https://www.pcori.org/about-us)

NIHR. See Table 1 for the NIHR definition of "public involvement in research." NIHR's INVOLVE provides the following additional definitions pertinent to the NIHR:

Involvement - where members of the public are actively involved in research projects and research organisations. Engagement - where information and knowledge about research is provided and disseminated. Participation - where people take part in a research study. (https://www.nihr.ac.uk/patients-and-public/) (see also INVOLVE ${ }^{18}$ )

The term "engagement" therefore means something different in the UK than in other countries. Nonetheless, the concept of involvement is the UK analog to the engaged research concept examined here. The NIHR definition of patient and public involvement (PPI) is similar to the CIHR and PCORI definitions of engaged research, emphasizing partnership:

An active partnership between patients and the public and researchers in the research process, rather than the use of people as 'subjects' of research. Patient and public involvement in research is often defined as doing research 'with' or 'by' people who use services rather than 'to', 'about' or 'for' them. (http://www. invo.org.uk/resource-centre/jargon-buster/?letter=P) 
Table 1 Definitions of Engaged Research from Four Major Funders

\begin{tabular}{|c|c|c|c|}
\hline$\overline{\text { CIHR }}$ & PCORI & NIHR & NHMRC \\
\hline $\begin{array}{l}\text { "Patient-oriented research } \\
\text { refers to a continuum of } \\
\text { research that engages } \\
\text { patients as partners, } \\
\text { focusses on patient- } \\
\text { identified priorities and } \\
\text { improves patient out- } \\
\text { comes. This research, } \\
\text { conducted by multidisci- } \\
\text { plinary teams in partner- } \\
\text { ship with relevant } \\
\text { stakeholders, aims to ap- } \\
\text { ply the knowledge gener- } \\
\text { ated to improve healthcare } \\
\text { systems and practices." } \\
\text { (http://www.cihr-irsc.gc. } \\
\text { ca/e/48413.html). } \\
\text { "Patient engagement } \\
\text { occurs when patients } \\
\text { meaningfully and actively } \\
\text { collaborate in the } \\
\text { governance, priority } \\
\text { setting, and conduct of } \\
\text { research, as well as in } \\
\text { summarizing, distributing, } \\
\text { sharing, and applying its } \\
\text { resulting knowledge (i.e., } \\
\text { the process referred to as } \\
\text { 'knowledge translation'). } \\
\text { It is of vital importance as } \\
\text { engaging patients in } \\
\text { health care research } \\
\text { makes [investments in] } \\
\text { research more accountable } \\
\text { and transparent, provides } \\
\text { new insights that could } \\
\text { lead to innovative } \\
\text { discoveries, and ensures } \\
\text { that research is relevant to } \\
\text { patients' concerns ..." } \\
\text { (http://www.cihr-irsc.gc. } \\
\text { ca/e/45851.html). }\end{array}$ & $\begin{array}{l}\text { "By 'engagement in } \\
\text { research' we refer to the } \\
\text { meaningful involvement } \\
\text { of patients, caregivers, } \\
\text { clinicians, and other } \\
\text { healthcare stakeholders } \\
\text { throughout the research } \\
\text { process - from topic } \\
\text { selection through design } \\
\text { and conduct of research } \\
\text { to dissemination of } \\
\text { results. We believe that } \\
\text { such engagement can } \\
\text { influence research to be } \\
\text { more patient centered, } \\
\text { useful, and trustworthy } \\
\text { and ultimately lead to } \\
\text { greater use and uptake } \\
\text { of research results by } \\
\text { the patient and broader } \\
\text { healthcare community." } \\
\text { (https://www.pcori.org/ } \\
\text { engagement/what-we- } \\
\text { mean-engagement) }\end{array}$ & 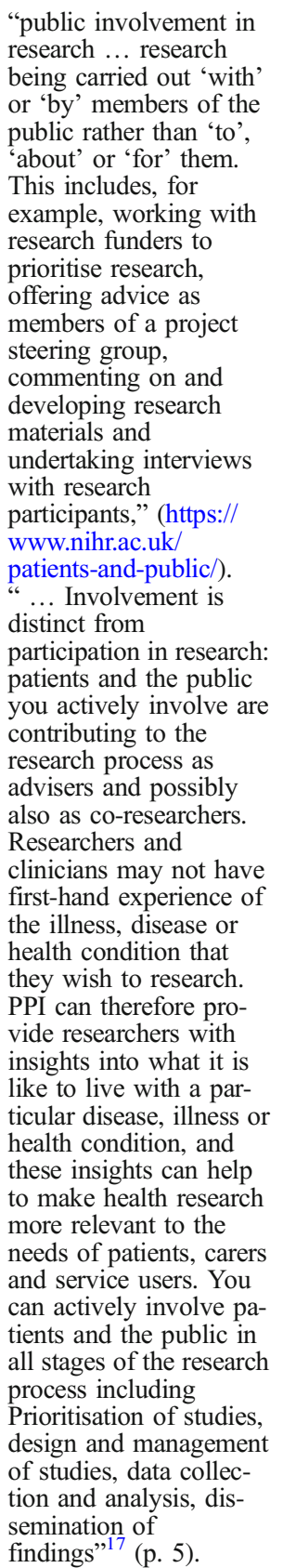 & $\begin{array}{l}\text { "Consumer and community involvement is about } \\
\text { research being carried out with or by consumers } \\
\text { and community members rather than to, about or } \\
\text { for them."12 } \\
\text { "Research engagement defined: Much of the policy } \\
\text { discussion in Australia around maximising the benefits } \\
\text { of publicly funded research ... has focussed on } \\
\text { measuring research impact. Broadly defined, research } \\
\text { impact is the 'demonstrable contribution that research } \\
\text { makes to the economy, society, culture, national security, } \\
\text { public policy or services, health, the environment, or } \\
\text { quality of life, beyond contributions to academia.' This } \\
\text { approach is focussed on the late stages of a research process. } \\
\text { Research engagement, by contrast, is defined as follows: } \\
\text { Engagement describes the interaction between researchers } \\
\text { and research organisations and their larger communities/industries } \\
\text { for the mutually beneficial exchange of knowledge, } \\
\text { understanding and resources in a context of partnership and } \\
\text { reciprocity." (https://www.atse.org.au/content/publications/ } \\
\text { report/industry-innovation/research-engagement-for-australia. } \\
\text { aspx, p. 4; http://www.arc.gov.au/engagement-and-impact-- } \\
\text { assessment) }\end{array}$ \\
\hline
\end{tabular}

In material directed at researchers, the NIHR provides guidance that emphasizes involvement across different stages of research. Like the CIHR definition, the NIHR language indicates that inclusion of patients is required for engagement (see Table 1).

The mission expressed by INVOLVE is similar to that of PCORI indicating an ultimate goal of improving "the health, wellbeing and wealth of the nation". ${ }^{18}$ The rationale for PPI emphasizes inclusion of patient and public voice in order to provide contributions distinct from those of researchers and clinicians. The focus for this PPI definition is on the contributions of engagement to specific research projects rather than to broader, societal level goals.

Australian National Health and Medical Resource Council. The Australian Code for the Responsible Conduct of Research ${ }^{19}$ encourages "Appropriate consumer involvement in research." The Australian statement about consumer and community involvement includes "planning, seeking funding, conducting the research, and communicating the outcomes." As with the 
Table 2 Comparison of Major Funder Definitions of Engaged Research

\begin{tabular}{|c|c|c|c|c|}
\hline & CIHR & PCORI & NIHR & NHMRC \\
\hline \multicolumn{5}{|l|}{ Who } \\
\hline \multicolumn{5}{|c|}{ Who does research engagement involve? } \\
\hline $\begin{array}{l}\text { Patients as partners } \\
\text { required for definition? }\end{array}$ & Yes & No & Yes & No \\
\hline $\begin{array}{l}\text { Patients as partners part } \\
\text { of definition? }\end{array}$ & Yes & Yes & Yes & Yes \\
\hline $\begin{array}{l}\text { Other stakeholders } \\
\text { referenced? }\end{array}$ & Yes & Yes & Yes & Yes \\
\hline \multicolumn{5}{|l|}{ Why } \\
\hline $\begin{array}{l}\text { Is rationale for definition } \\
\text { expressed in terms of } \\
\text { social action/equity? }\end{array}$ & Yes & No & Yes & No \\
\hline \multicolumn{5}{|c|}{ What are goals of research engagement? } \\
\hline $\begin{array}{l}\text { Improving research } \\
\text { uptake }\end{array}$ & Yes & Yes & Yes & Yes \\
\hline $\begin{array}{l}\text { Improving decision } \\
\text { making in health }\end{array}$ & Yes & No & No & No \\
\hline \multicolumn{5}{|l|}{ How } \\
\hline \multicolumn{5}{|c|}{ In what ways is research engagement implemented? } \\
\hline $\begin{array}{l}\text { Address patient } \\
\text { priorities }\end{array}$ & Yes & Yes & No* & No \\
\hline $\begin{array}{l}\text { Conduct research in } \\
\text { teams }\end{array}$ & Yes & Yes & No & No \\
\hline \multicolumn{5}{|l|}{ What } \\
\hline $\begin{array}{l}\text { Does the definition } \\
\text { include an intensity } \\
\text { grading? (from limited } \\
\text { to active engagement) }\end{array}$ & Yes & No & No & No \\
\hline
\end{tabular}

CIHR and NIHR definitions, this encompasses more than just involvement in a specific research project, but consonant with the definitions from each of the other major funders examined here, the Australian definition stresses partnership. An Australian report on research engagement references broad societal contributions of engagement, representing a global set of goals like CIHR and NIHR (see Table 1).

\section{In the literature}

There is a relationship between literature-derived definitions of engaged research and definitions of funding agencies, both because the literature is influenced by definitions of major funders explicitly and implicitly, and because funders have used literature-based features in assembling their definitions. It is instructive to consider the literature-based definitions separately, however, as they reflect a wider set of views free of constraints of government-attached funding agencies. While there are over 200 articles addressing engaged research definitions from 1995 to present per the search conducted (see Appendix 1, online), four articles from the last decade provide particularly important contributions to defining research engagement. ${ }^{20-23}$ Each can trace their conceptual frame to Arnstein's ladder of citizen participation, ${ }^{24}$ in which a continuum of involvement, from passive to active control, is made explicit in terms of citizen participation in civic activities. For example, Goodman and colleagues ${ }^{20}$ present a stakeholder engagement classification continuum of non-participation, symbolic participation, and engaged participation. The last category (engaged participation) corresponds to Arnstein's highest level of active control. They go on to define further classifications as outreach, education, coordination, cooperation, collaboration, patient-centered, and CBPR.

The framework presented by Tritter $^{22}$ also captures the intensity grading evident in Arnstein's ladder, with a distinction between indirect and direct involvement: the degree to which mediators are or are not involved between participants and decisions. The framework also adds distinctions between individual and collective involvement to address individual treatment decisions and system-level care elements. Of particular relevance to definitions is the distinction between proactive and reactive involvement. In proactive involvement, participants coproduce decisions or agendas with researchers. Proactive involvement is therefore higher on Arnstein's ladder, representing more active control of the work and the interaction with researchers than reactive involvement. As an example, if researchers convene participants to discuss an agenda or specific research questions determined by the researchers rather than coproducing a research agenda with participants, then this involvement is reactive. The distinction between proactive and reactive involvement is helpful for understanding definitions of engagement because of the intensity of partnership the distinction indicates, from a low level of partnership with reactive involvement to a high level of partnership with proactive involvement. Patient or citizen panels are not automatically partners or co-producers if their role is to "react" to an agenda or a set of questions brought to them by researchers.

Oliver and colleagues ${ }^{23}$ present a framework for public involvement in research that focuses on involvement drivers, involvement processes, and involvement impacts. All three are relevant to defining research engagement and distinguishing between the who, why, and how (see Table 2).

Goodyear-Smith ${ }^{21}$ provides a useful overview of relevant terminology and "taxonomical challenges" involved in defining participatory research, action research, participatory action research, CBPR, and community-academic-partnered participatory research. She notes "The proliferation of terminology used to describe this research genre requires development of a robust taxonomy to categorize overlapping concepts where engagement of end users in the research process is core" ( $p$. 268). While she identifies participant engagement as a philosophy, not a methodology, we categorize it as a philosophical approach with ethical motivations as well as a research method with empirical support (see for example Frank et al. ${ }^{11}$ in which the ethical imperatives are acknowledged along with empirical rationale).

\section{DISCUSSION}

The field of engaged research has developed from the late twentieth century through the present, with foundations in 
Table 3 Stakeholder Definitions in Funder Description of Engaged Research

\begin{tabular}{|c|c|c|c|}
\hline$\overline{\text { CIHR }}$ & PCORI & NIHR & NHMRC \\
\hline $\begin{array}{l}\text { SPOR Partner: "key } \\
\text { stakeholders collaborating in } \\
\text { patient-oriented research, such } \\
\text { as the SUPPORT Unit jurisdic- } \\
\text { tional leads for each province } \\
\text { and territory, patients, re- } \\
\text { searchers, policy makers, } \\
\text { decision-makers, health organi- } \\
\text { zations, provincial/territorial } \\
\text { health authorities, academic in- } \\
\text { stitutions, charities and the } \\
\text { pharmaceutical sector." (http:// } \\
\text { www.cihr-irsc.gc.ca/e/48413. } \\
\text { htmll) } \\
\text { "The meaningful involvement } \\
\text { of patients can include the } \\
\text { following roles: As research } \\
\text { committee members, planning, } \\
\text { designing and guiding the } \\
\text { project as it progresses. This } \\
\text { involvement in decision-making } \\
\text { processes and in bringing for- } \\
\text { ward priority issues for research } \\
\text { is integral to patient-oriented } \\
\text { research, as competent patient } \\
\text { engagement researchers They } \\
\text { have mastered the specific re- } \\
\text { search skills and know how to } \\
\text { engage other patients, capture } \\
\text { and articulate their ideas, sup- } \\
\text { port these ideas with valid } \\
\text { research, and bring them to the } \\
\text { table. As contributors to identi- } \\
\text { fying the right research } \\
\text { question, study design, } \\
\text { recruitment, data collection, and } \\
\text { analysis of findings. Patients } \\
\text { can also have a role in } \\
\text { reviewing stories to identify } \\
\text { common threads/relevant } \\
\text { themes. This ensures that the } \\
\text { outcomes important to patients } \\
\text { are supported and measured. As } \\
\text { supporters of } \\
\text { participant-friendly research } \\
\text { studies, improving access to } \\
\text { patients via peer networks and } \\
\text { accessing difficult-to-reach pa- } \\
\text { tients and groups." (http://www. } \\
\text { cihr-irsc.gc.ca/e/48413.html) }\end{array}$ & $\begin{array}{l}\text { "A broad range of } \\
\text { communities have a stake } \\
\text { in the effectiveness of our } \\
\text { healthcare system. In the } \\
\text { term patient partners, we } \\
\text { include patients who are } \\
\text { representative of the } \\
\text { population of interest in a } \\
\text { particular study, as well as } \\
\text { their family members, } \\
\text { caregivers, and the } \\
\text { organizations that represent } \\
\text { them. Other stakeholder } \\
\text { partners include members } \\
\text { of constituencies based on } \\
\text { professional, rather than } \\
\text { personal, experience. These } \\
\text { can include clinicians, } \\
\text { healthcare purchasers, } \\
\text { payers, industry, hospitals } \\
\text { and other health systems, } \\
\text { policy makers, training } \\
\text { institutions, and } \\
\text { researchers. Some } \\
\text { individuals may fit into } \\
\text { several categories," (https:// } \\
\text { www.pcori.org/ } \\
\text { engagement/what-we- } \\
\text { mean-engagement) }\end{array}$ & $\begin{array}{l}\text { "The term research partner is used to describe } \\
\text { people who get actively involved in research, to the } \\
\text { extent that they are seen by their "professional' } \\
\text { colleagues as a partner, rather than someone who } \\
\text { might be consulted occasionally. Partnership } \\
\text { suggests that researchers and service users/carers } \\
\text { have a relationship that involves mutual respect and } \\
\text { equality," http://www.invo.org.uk/resource-centre/ } \\
\text { jargon-buster/) } \\
\text { "researcher:" } \\
\text { "Researchers are the people who do the research. } \\
\text { They may do research for a living, and be based in } \\
\text { a university, hospital or other institution, and/or } \\
\text { they may be a service user or carer," (http://www. } \\
\text { invo.org.uk/resource-centre/jargon-buster/page/2/? } \\
\text { letter=R) } \\
\text { "When we use the term 'public' we are including } \\
\text { patients, potential patients, carers and people who } \\
\text { use health and social care services as well as people } \\
\text { from organisations that represent people who use } \\
\text { services. Whilst all of us are actual, former or } \\
\text { indeed potential users of health and social care } \\
\text { services, there is an important distinction to be } \\
\text { made between the perspectives of the public and } \\
\text { the perspectives of people who have a professional } \\
\text { role in health and social care services" } \\
\text { (https://www.nihr.ac.uk/patients-and-public/). } \\
\text { "The term PPI covers a wide variety of individual } \\
\text { people as well as groups and organisations. ... } \\
\text { People who use, or have used, health or social care } \\
\text { services; • informal (unpaid) carers and family } \\
\text { members; • parents; } \bullet \text { members of the general } \\
\text { public; • organisations who represent patients and } \\
\text { users; • patient support groups; • charities that } \\
\text { represent specific health conditions; • individuals } \\
\text { with an interest in the topic being researched." }\end{array}$ & $\begin{array}{l}\text { Community: "a group of } \\
\text { people sharing a common } \\
\text { interest (e.g. cultural, social, } \\
\text { political, health, economic } \\
\text { interests) but not necessarily } \\
\text { a particular geographic } \\
\text { association. Different types of } \\
\text { communities are likely to } \\
\text { have different perspectives } \\
\text { and approaches to their } \\
\text { involvement in research." } \\
\text { Consumers: "patients and } \\
\text { potential patients, carers, and } \\
\text { people who use health care } \\
\text { services ... Collectively, } \\
\text { "consumers' and 'community } \\
\text { members' may be referred to } \\
\text { as 'the public." } \\
\text { Stakeholder: "An individual } \\
\text { or group from within or } \\
\text { outside research organisations } \\
\text { with a key interest in } \\
\text { research. This might include } \\
\text { members of consumer } \\
\text { organisations, professional } \\
\text { bodies, government agencies, } \\
\text { non-government } \\
\text { organisations, industry, or re- } \\
\text { search funders as well as } \\
\text { consumers and community } \\
\text { members. Stakeholders can } \\
\text { provide support or expertise } \\
\text { and may influence decisions } \\
\text { about the research and its } \\
\text { findings.". .2 }\end{array}$ \\
\hline
\end{tabular}

CBPR and political activism. The political and advocacy roots of engaged research are reflected in definitions of engagement expressed over the past 10 years and in definitions of stakeholders of engaged research which include communities affected by the research. The unique focus on clinical research, however, rather than on advocacy as with CBPR, has led to a distinct set of stakeholders: individuals who are most proximally affected by the clinical research for health decision making. Engagement itself is conceptualized and defined with reference to research project goals, from goals designed to inform very specific clinical decisions, to goals designed to inform health-system-level decisions. The potential for engaged research to inform policy change is reflected in major funder definitions, although the definitions vary in terms of extent to which they emphasize broad public health impact over impact on specific clinical decisions.
An additional consideration relevant to defining engaged research is the role of stakeholders. Several funders and many other researchers use the term "service users" as the target for engaged research. ${ }^{25,26}$ The definitions of research engagement and stakeholders examined here reference the targets as well as goals of the research.

Warsh ${ }^{13}$ points to the problematic aspects of grouping "patient" with "public" involvement, as is done explicitly in the UK with definitions and operationalization of "patient and public involvement" (see also Fredriksson and Tritter $^{27}$ on the importance of distinguishing between them). As Tritter ${ }^{22}$ notes, involvement can be indirect or direct. Funder definitions allow for both direct and indirect involvement as well as both proactive and reactive involvement.

Unlike the definitions of engaged research from the other major funders, PCORI does not explicitly reference social 


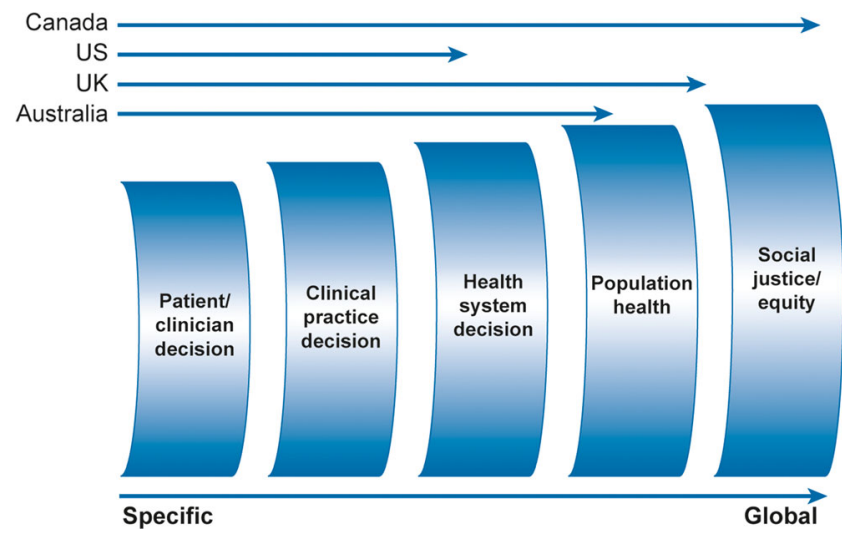

Figure 1 Definitions of engaged research: comparison by four international major funders of engaged research.

justice and equity as a goal of engaged research, although specific PCORI funding initiatives address health disparities. The source materials selected for these cross-funder comparisons emphasize definitions. The wider set of materials and funding programs of any given funder address a wider scope than that presented here. In addition, the definitions express proximal goals. More distal goals of clinical research for these funders converge on global population health. Political as well as cultural differences in healthcare systems across the countries are likely relevant to understanding between-funder differences, including country-specific health technology assessment processes and goals.

Relative to definitions of engaged research from major funders, definitions found in the literature from the end of the last century through the present include more reference to ethical rationales for engagement. A few related issues likely account for this difference. While some research funders acknowledge ethical imperatives, as funders of empirical clinical research the focus is on empirical rather than ethical rationales. This raises an interesting connection between the role of government in supporting ethical values through its activities and the distancing of government funders from wider issues of values. Political expedience may lead funders to emphasize focus on tangible rationales and outcomes to avoid entering contentious discussions of values that should underlie research funding. Countries with centralized and advanced systems of health technology assessment, however, have a natural link between societal values and funded research, and may therefore be less reticent about the link between ethical imperatives for engagement and the engagement requirement in clinical research.

The framework for categorizing "drivers, process and impacts" presented by Oliver and colleagues ${ }^{23}$ is extremely useful as a guide to selecting engagement models to implement and as a means for evaluating and comparing different research engagement activities. Categories of stakeholders are largely similar across major funders and published stakeholder frameworks, and tracing their placement on a continuum from research project-specific to more global and public health connected mirrors the "specific" to "global" continuum observed across definitions of research engagement.

Terms have not been static over the past 15 years, although there is convergence on conceptual equivalence. Comparing across the continuum from specific patient/clinician dyad activities to initiatives with social justice aims clarifies the path forward for defining engagement.

\section{Terminology Recommendations}

We recommend harmonization among patients, healthcare providers, researchers, and funding agencies, mindful of encouraging continued innovation and diversity in approaches. "Engagement" should be the preferred term for active involvement as research partners, allowing distinction from research subject "participation." "Involvement" includes activities beyond research and should be reserved for societal level activities such as priority setting and aiding with research dissemination-activities outside of participation in specific research projects. "Public involvement" and "consumer involvement" are overly narrow terms since a range of stakeholders, including those not identified as members of the non-researcher public, can be legitimate partners in engaged research. The term "patientoriented research" is too broad to be part of harmonized terminology, since all clinical research can be considered patient-oriented. This term also suggests a focus on public health and applied research. Engaged research can include basic as well as applied research. "Research engagement" then should be defined as active partnership between stakeholders and researchers in production of new healthcare knowledge and evidence. Adoption of these definitions avoids the challenges posed by the different meanings for similar terms across funders and researchers.

Given continued development of the field and given the likelihood that engagement approaches will continue to proliferate, consensus on definitions based on the recommendations here would enable research engagement elements, methods, and outcomes and impacts to be examined and understood, moving the field of research engagement forward from a clear conceptual foundation.

Acknowledgments: The authors wish to thank MuSE project manager Jennifer Vincent and members of the Muse Working Group 1: Arnav Agarwal; Pauline Campbell; Rachel Churchill; Ian Graham; Sean Grant; Vittal Katikireddi; Claire Kendall; Lyuba Lytvyn; Pua Motu'apuaka Makalapua; Jennifer Petkovic; Kevin Pottie; Alex Pollock; Alison Riddle; Rosiane Simeon; Annie Synnot; Ellen Tambor; Vivian Welch.

Corresponding Author: Lori Frank, PhD; RAND Corporation, Washington, DC, USA (e-mail: LFrank@RAND.org).

\section{Compliance with Ethical Standards:}

Conflict of Interest: SCM is a member of the PCORI Methodology Committee. TC worked with PCORI under contract within the prior 3 years. LF was employed by PCORI through 2018. All other authors declare no conflicts of interest specific to this manuscript. 


\section{REFERENCES}

1. Berridge V. Public health activism: lessons from history? BMJ. 2007;335(7633):1310-1312.

2. Tomes N. The Patient as a Policy Factor: A Historical Case Study of The Consumer/Survivor Movement in Mental Health. Health Aff 2006; 25(3):720-729.

3. Wallerstein $\mathbf{N}$ and Duran B. Chapter 2: The conceptual, historical and practical roots of community based participatory research and related participatory traditions. In Minkler M and Wallerstein (Eds). Community Based Participatory Research for Health. From process to outcomes. San Francisco: Jossey-Bass; 2003.

4. Scott D. The untold story of TV's first prescription drug ad. Stat News. 2015. https://www.statnews.com/2015/12/11/untold-story-tvs-firstprescription-drug-ad/. Accessed 29 Aug 2019.

5. Briggs JS, Early GH. Internet developments and their significance for healthcare. Med Inform Internet Med. 1999;24(3):149-64.

6. Tomes N. From Outsiders to insiders. Chapter 5: The consumer-survivor movement and its impact on US mental health policy. In Hoffman B, Tomes N, Grob R, and Schlesinger M (Eds). Patients as policy actors. New Brunswick: Rutgers University Press; 2011

7. Charlton, JI. Nothing about us without us: Disability oppression and empowerment. Berkeley: University of California Press. 2000.

8. INVOLVE. Briefing notes for researchers: involving the public in NHS public health and social care research. Eastleigh: INVOLVE; 2012

9. Partridge N, Scadding $\mathbf{J}$. The James Lind Alliance: patients and clinicians should jointly identify their priorities for clinical trials. Lancet 2004; 364(9449): 1923-1924.

10. Canadian Institutes of Health Research (CIHR) . 2011. Canada's Strategy for Patient-Oriented Research Oriented Research. Improving health outcomes through evidence-informed care. Available at: http://www. cihr-irsc.gc.ca/e/44000.html. Accessed 29 Aug 2019.

11. Frank L, Basch E, Selby JV. The PCORI perspective on patient-centered outcomes research. JAMA. 2014;312(15):1513-4.

12. Consumers Health Forum of Australia. Statement on Consumer and Community Involvement in Health and Medical Research, National Health and Medical Research Council. 2016. Available at: https://www. nhmrc.gov.au/guidelines-publications/s01. Accessed 29 Aug 2019.

13. Warsh J. PPI: understanding the difference between patient and public involvement. Am J Bioeth. 2014;14(6):25-6.
14. Williamson L. Patient and citizen participation in health: the need for improved ethical support. Am J Bioeth. 2014;14(6):4-16.

15. Concannon TW, Grant S, Welch V, Petkovic J, Selby J, Crowe S, Synnot A, Greer-Smith R, Mayo-Wilson E, Tambor E, Tugwell P, for the Multi Stakeholder Engagement (MuSE) Consortium. Practical Guidance for Involving Stakeholders in Health Research. J Gen Intern Med. 2019;34(3):458-463. https://doi.org/10.1007/s11606-018-4738-6.

16. Selby JV, Slutsky JR. Practicing partnered research. J Gen Intern Med. 2014; 29(Suppl 4):814-6.

17. NIHR 2014. Patient and public involvement in health and social care research: A handbook for researchers. National Health Service.

18. INVOLVE. NIHR-wide learning and development for public involvement: working group report and recommendations, Eastleigh: INVOLVE; 2015

19. Australian Code for Responsible Conduct of Research. 2007. Available at: www.nhmrc.gov.au/guidelines-publications/r39. Accessed 29 Aug 2019.

20. Goodman MS, Sanders Thompson VL. The science of stakeholder engagent in research: classification, implementation, and evaluation. Transl Behav Med. 2017; 7(3): 486-491.

21. Goodyear-Smith F. Collective enquiry and reflective action in research: towards a clarification of the terminology. Fam Pract. 2017;34(3):268271.

22. Tritter JQ. Revolution or evolution: the challenges of conceptualizing patient and public involvement in a consumerist world. Health Expect. 2009; 12(3):275-87.

23. Oliver S, Liabo K, Stewart R, Rees R. Public involvement in research: making sense of the diversity. J Health Serv Res Policy 2015; 20(1):45-51.

24. Arnstein SR. A Ladder of Citizen Participation. JAIP, 1969; (4):216-224.

25. Wright D, Foster C, Amir Z, Elliott J, Wilson R. Critical appraisal guidelines for assessing the quality and impact of user involvement in research. Health Expect. 2010;13(4):359-68.

26. Callard F, Rose D, Wykes T. Close to the bench as well as at the bedside: involving service users in all phases of translational research. Health Expect. 2012;15(4):389-400.

27. Fredriksson $\mathbf{M}$, Tritter JQ. Disentangling patient and public involvement in healthcare decisions: why the difference matters. Sociol Health Illn. 2017;39(1):95-111

Publisher's Note Springer Nature remains neutral with regard to jurisdictional claims in published maps and institutional affiliations. 